\title{
Starters, groeiers en durfkapitaal
}

\section{Inleiding}

De opkomst van jonge, groeiende ondernemingen in de jaren tachtig leidt tot snelle ontwikkelingen in de financiering en begeleiding van deze bedrijven. Begrippen als venture capital, starters, buy-outs en hightech verkrijgen een nog steeds toenemende bekendheid, en nieuwe vormen van dienstverlening ontstaan. De literatuur hierover groeit; auteurs van diverse professies publiceren artikelen, congresbijdragen en boeken, waarin visies en adviezen worden weergegeven.

Directe aanleiding tot dit artikel was dan ook een tweetal besprekingsverzoeken door de redactie van het MAB. Deze verzoeken betroffen de boeken Eigen Bedrijf? Adviezen voor de startende ondernemer (redactie: Prof. Mr. Drs. J. Th. Degenkamp) ${ }^{1}$ en Venture Capital Gids '85-'86 (uitgave Peat Marwick Nederland $)^{2}$. Deze boeken worden in paragraaf 2 besproken. Teneinde echter deze boeken juist te kunnen plaatsen, leek een iets bredere behandeling gewenst. Daartoe wordt in paragraaf 3 een beknopt overzicht gegeven van ontwikkelingen in het Nederlandse ondernemingsklimaat. Dit leidt in paragraaf 4 tot een analyse van 'lokale werkgelegenheidsinitiatieven' en 'venture capital'. Tenslotte vindt in paragraaf 5 een afgrenzing van deze begrippen plaats, gevolgd door een korte evaluatie van de besproken ontwikkelingen.

\section{Boekbespreking}

2.1 Degenkamp c.s. 'Eigen bedrijf? Adviezen voor de startende ondernemer' Dit boek heeft betrekking op de wereld der lokale werkgelegenheidsinitiatieven (zie paragraaf 4), en is ontstaan op basis van een cursus 'Een eigen bedrijf beginnen' in 1982, georganiseerd door de Vakgroep Recht van de Economische Faculteit der Rijksuniversiteit Groningen. Men vindt in dit boek verhandelingen over vele facetten van de startende onderneming: rechtsvorm, financiering (onder andere de staatsgegarandeerde kredieten), inkomsten-/vennootschapsbelasting, vestigingsbepalingen, liquiditeitsbehoefte en -planning, marketing, sociale wetgeving, handelsregister en tenslotte de administratievoering.

Inhoudelijk acht ik de bijdragen over het algemeen instructief, helder en (uiteraard) deskundig. Desalniettemin enige kleine kritische kanttekenin- 
gen, aangezien enkele voor starters essentiële punten niet of onvoldoende worden behandeld. Bijvoorbeeld:

- Het aanstaande verdwijnen van de 'negatieve voorlopige aanslag' voor de WIR-premies wordt niet gememoreerd (p. 33), terwijl starters toch regelmatig denken, dat deze premies bijna direct ontvangen worden.

- Gesteld wordt, dat de kleinere BV 'geen of slechts een beperkte publikatieplicht' kent (p. 45). 'Geen of' is feitelijk onjuist.

- De WIR-premiepercentages op p. 57 zijn die, welke golden tot 1 januari $1984(!)$.

- Op p. 79 wordt een liquiditeitsoverzicht gepresenteerd, waarbij nettoontvangsten worden vermeld, zonder aan te geven dat deze negatief zijn (dat blijkt pas uit de bestudering) en zonder te werken met begin-en eindsaldi; een methodiek, die toch in vele boekjes is terug te vinden en zijn praktische toepasbaarheid heeft bewezen. Voorts blijkt de relatie met de eigen vermogensinbreng niet, en zijn de belastingen te abstract verwerkt.

- Gemist wordt een handreiking inzake pensioenen en zelfstandigenverzekeringen.

- De paragraaf over de administratievoering is wel zeer geschreven op het (detailhandels)kleinbedrijf, waardoor de strekking nogal beperkt wordt: ontbreken van liquiditeitsoverzichten, toepassen van vermogensvergelijking als basis voor de winstbepaling, ontbreken van enige opmerking over BTW-teruggaaf faciliteiten bij import, software die voor 'relatief weinig geld' te koop is.

De vraag rijst nu, voor wie dit boek nuttig is. Ik betwijfel de relevantie voor de starter, zeker als hij detaillist is vanwege de uitgebreidheid, gedetailleerdheid, en het vooronderstelde kennisniveau. Mijns inziens kan een dergelijke starter beter de beschikbare brochures opvragen bij banken ${ }^{3}$, om daarna inhoudelijk te gaan praten met bankier en accountant ${ }^{4}$. Voor de accountant/adviseur in het kleinbedrijf kan het boek van Degenkamp echter bepaald nuttig zijn. De kennis, aldaar beschreven, dient ongeveer bij de accountant/adviseur paraat te zijn, en derhalve kan dit boek nuttige diensten bewijzen als checklist en brede voorlichting, zodat het bijeensprokkelen van kennis in tijd bekort kan worden.

\subsection{Venture Capital Gids (Peat Marwick)}

De VC-Gids is geschreven voor een heel andere doelgroep: ondernemers, adviseurs en participanten in de venture capital wereld. Het boek bevat een up-to-date overzicht van venture capital-verschaffers en -bemiddelaars, alsmede actuele beschouwingen van deskundige auteurs over internationale ontwikkelingen, de vele aspecten die bij venture capital een rol spelen, en adviezen voor het opstellen van een ondernemingsplan. De actualiteit moge onder andere blijken uit het feit, dat dit boek op 1 oktober 1985 beschikbaar was, met cijfers over onder andere ontwikkelingen op de Parallelmarkt en bij PPM's per 30 juni 1985. De beschrijvende gedeeltes zijn voor insiders niet nieuw, maar waren tot nog toe vrijwel uitsluitend Engelstalig beschikbaar (zie de literatuur bij noot 12 en 15). Verdienste van de vC-Gids is 
daarom onder meer het vrij complete overzicht van de Nederlandse markt en de Nederlandstaligheid.

Ook hier mogen echter enkele kritische kanttekeningen niet ontbreken.

- De 'Gids' heeft duidelijk haast gehad, het belang van actualiteit heeft er toe geleid, dat in lay-out en druk nog wel eens iets is misgegaan. Bij vergelijking met de vorige editie blijken soms halve zinnen verdwenen.

- De recapitulatie van een onder venture capital verschaffers gehouden enquête (p. 105 e.v.) lijdt - zoals uit de tekst ook blijkt - onder de slechts gedeeltelijke beantwoording $( \pm 57 \%)$. Hierdoor moeten de getallen over geïnvesteerde bedragen en verdeling in de markt nogal globaal geïnterpreteerd worden.

De feitelijke overzichten sluiten dan ook niet altijd op elkaar aan (men vergelijke o.a. de NEOM op p. 107, 108 en 172; onduidelijk is, of de NEOM nu 3,20 of 30 participaties heeft, voor $f 1$ miljoen of $f 215$ miljoen).

- Genoemde enquête heeft ertoe geleid, dat bij de benoeming van relevante venture capital bedrijfstakken thans (anders dan in de eerste editie) toegevoegd is en als nummer één geplaatst 'metaal en metaalverwerking'. Het komt mij voor, dat hier enig nader onderzoek nuttig is, vanwege de invloed van de Nederlandse Participatiemaatschappij (NPM) en de ruime omschrijving van deze branche, welke vermoedelijk teveel ruimte laat voor de historische bedrijfssituatie in Nederland en het innovatie/hightech aandeel hierin versluiert.

- Meer principieel is de zinsnede (inzake het ondernemingsplan, p. 24): 'Centraal staat de winst en cash flow prognose'. Dit lijkt mij te zwaar geformuleerd. Genoemde staten zijn ongetwijfeld belangrijk, maar niet centraal. Centraal staat de beoordeling van de ondernemer en zijn produkt/marktmatrix. Bij David Silver (Who's who, noot 12) trof ik de formule: $\mathrm{V}=\mathrm{P} \times \mathrm{S} \times \mathrm{E}$, hetgeen staat voor: Valuation $=$ Problem $\times$ Solution $\times$ Entrepreneurial Team. Hiermee lijkt mij goed gedefinieerd, wat centraal staat.

- Tenslotte: op p. 33 wordt als alternatief voor een 'formeel accountantsrapport' genoemd de 'businessman's review', zijnde een meer inhoudelijk accountantsverslag (zonder 'goedkeurende verklaring'). De gedachte van een meer inhoudelijke en management gerichte rapportage lijkt mij juist. Maar te suggestief acht ik de mededeling, dat zo'n review (een 'BMR' in het jargon) 'aanzienlijk goedkoper' is dan het formele accountantsrapport. Het zal Peat niet onbekend zijn, dat een BMR met name gebruikt wordt bij het beoordelen van potentiële overname-kandidaten (vandaar de alternatieve benaming 'preacquisition review', ook wel: 'investigation'), waarbij vooraf met de opdrachtgever duidelijk de omvang en diepgang van deze review worden afgesproken. Met andere woorden: de kosten van een BMR zijn geheel variabel met de door de opdrachtgever gewenste diepgang.

Ondanks deze kanttekeningen kan gesteld worden, dat deze 'Venture Capital Gids' een handzaam overzicht biedt van de huidige Nederlandse Venture Capital-markt. Zowel insiders als nieuwkomers in deze markt kunnen er veel nuttige informatie aan ontlenen. 


\section{Het ondernemingsklimaat in Nederland: een terugblik}

De in paragraaf 2 besproken boeken zijn illustratief voor de grote veranderingen die zich in het afgelopen decennium hebben voorgedaan in de waardering en verwerkelijking van het ondernemerschap. Zonder enige pretentie van volledigheid zij het navolgende genoemd.

1 De maatschappelijke waardering voor het ondernemen is sterk gestegen. Er mag sinds enkele jaren weer zonder schroom over winst, rendement, dividend gesproken worden. De tijden gaan snel - maar het is nog niet zo lang geleden dat ondernemers zich bepaald miskend en ondergewaardeerd voelden.

2 Werkgelegenheid, ook in hogere functies, is geen vanzelfsprekendheid meer. De zekerheid van een overheidsbetrekking of dienstverband in een grotere onderneming is verdwenen, evenals het daaraan gekoppelde postactieve inkomen. Ingrepen in pensioenrechten en ontslagen in overheidsdiensten waren tien jaar geleden nauwelijks denkbaar. De schoolverlatende jeugd heeft moeten leren leven met onzekerheid over een adequate baan.

3 De aantrekkelijkheid van en het vertrouwen in grote ondernemingen is minder vanzelfsprekend geworden. Déconfitures als OGEM en RSV waren tien jaar geleden ondenkbaar. Bewust geïnitieerde verzelfstandigingen uit grote concerns betekenden voor de betrokken werknemers een wezenlijke cultuurverandering; ${ }^{5}$ de beschermende concern-paraplu werd vervangen door de regenjas van een klein collectief.

4 Erkenning van en geloof in de kleinere onderneming is toegenomen. Mede veroorzaakt door de eerdergenoemde ontwikkelingen, maar ook los daarvan. De vele in de jaren tachtig gestarte kleine ondernemingen zijn lang niet altijd uit gebrek aan alternatieven gestart, maar vaak ook vanwege een positieve motivatie voor het opbouwen van een eigen onderneming met overzichtelijke en beheersbaar geachte perspectieven. Small werd beautiful, en kleinschaligheid werd bijna modieus.

5 Maatschappijkritisch denken heeft plaatsgemaakt voor een meer individuele levensopbouw. Men herinnert zich de studentenrevoluties einde zestiger jaren, de kritiek op de Affluent Society (Galbraith) en de 'Onedimensional man' (Marcuse). Kritiek op een luxe samenleving, die vanzelf moest wijken voor de welvaartsreductie, die in de jaren tachtig zijn intree deed. Men kan echter de maatschappijkritiek van toen ook zien als individualisering en groeiende assertiviteit van een generatie, die een eigen leven wilde opbouwen over gegroeide vanzelfsprekendheden heen. $\mathrm{Zo}$ bezien, is thans de sociologische constatering van de 'jappies' (young ambitious professionals) volstrekt begrijpelijk.

6 In dit verband zij ook genoemd de kritiek op het 'vooruitgangsgeloof' (ideologisch, B. Goudzwaard e.a., maar ook feitelijk, bijv. de 'Club van Rome'). Begrippen als eindigheid, beperktheid van natuurlijke grondstof- 
fen, het 'Derde-Wereld-probleem' en de 'Noord-Zuid tegenstelling' hebben bijgedragen aan het maatschappelijk besef, dat de vette jaren zeventig door magere jaren tachtig gevolgd werden, en dientengevolge nieuwe antwoorden op actuele vragen van werkgelegenheid en inkomensverwerving noodzakelijk waren.

7 Meer feitelijk is de constatering der sterk gestegen werkloosheid. Deze leidde tot een koortsachtig zoeken naar nieuwe werkgelegenheid. Waar aanvankelijk voornamelijk gedacht werd aan overheidsinvesteringen en -bijdragen, werd geleidelijk de aandacht meer gericht op de eigen bijdragen vanuit (vooral kleine) ondernemingen. Enerzijds was hieraan debet de zorg over het grote overheidstekort; anderzijds, en grotendeels los daarvan of zelfs eerder, ontstond de indruk dat voornamelijk in de 'small business' nog nieuwe werkgelegenheid mogelijk was. Hoewel cijfermateriaal daarover (ook uit de USA) niet altijd even overtuigend was $^{6}$, is de publieke opinie hierdoor meer gecharmeerd geraakt van de kleine onderneming. Dit heeft geleid tot een veelheid van 'lokale werkgelegenheidsinitiatieven', waarover aanstonds meer.

8 Voorts mag niet onvermeld blijven het groeiend bedrag aan voor investering beschikbare gelden bij institutionele beleggers, banken en particuliere groepen. Was slechts enkele jaren geleden nog de overheersende gedachte, dat voor investeringsprojecten nauwelijks gelden beschikbaar waren, inmiddels lezen we dagelijks dat de beschikbaarheid van kapitaal geen punt van discussie is. In snel tempo ontstonden de afgelopen jaren investeringsfondsen van diverse origine, en rees veelvuldig de vraag waar de beschikbare middelen in belegd konden worden.

9 Tenslotte de zeer snelle technologische ontwikkelingen. De popularisering van de computer, het belang van technologische innovatie, Silicon Valley als symbool van vernieuwd ondernemen, begrippen als telecommunicatie, netwerken, biotechnologie - het zij hier slechts genoemd om aan te duiden dat de samenleving in snel tempo vertrouwd raakt met grote veranderingen in communicatie en techniek. De research, development en marketing van een veelheid van produkten in deze sfeer betekende een originele impuls voor innoverend ondernemen.

Samenvattend zij gesteld, dat in de afgelopen jaren in snel tempo een klimaat is ontstaan, dat gunstig was voor het ontstaan van kleinere ondernemingen, gericht op nieuwere produkten. Risicovol ondernemen, individueel presteren en adequate beloning werd steeds positiever ervaren en van belang geacht voor welvaart en werkgelegenheid. Investeren in deze risico's en het daardoor bevorderen van werkgelegenheid ontving steeds meer aanmoediging. Men denke slechts aan de rapporten 'Een nieuw elan' van de zg. 'Commissie-Wagner'. Soms heeft men zelfs de indruk, dat de ontwikkeling vanuit grote concerns naar het entrepreneurship in kleine ondernemingen, ventures en recentelijk de management buy outs noodzakelijk was om het intrapreneurship in de grotere onderneming te herontdekken, of althans een sterke vernieuwingsimpuls te geven. ${ }^{?}$ 


\section{4 (Ver)nieuw(end) ondernemen}

Het resultaat van de hiervóór aangeduide ontwikkelingen heeft op zijn minst geleid tot een investering van veel energie in het bevorderen van nieuwe werkgelegenheid. Ook al zijn de aantallen nieuwe arbeidsplaatsen nog niet spectaculair, op vele plaatsen en wijzen zijn aanzetten gegeven die als eerste resultaat hebben een hernieuwd ondernemers-enthousiasme.

\subsection{Relevante ontwikkelingen in de USA en UK}

Wanneer we eerst een blik over de grenzen werpen, zijn 'Engeland' en 'Amerika' de twee gebieden die mijns inziens directe effecten voor ons land hebben gehad. 'Amerika' (USA), waar al gedurende zo'n dertig jaar bewust gewerkt wordt aan de stimulering van hoogwaardige 'Small business', in het bijzonder door het instituut der SBIC's (Small Business Investment Corporations). Essentieel in deze SBIC's is de formule om investeringsvermogen te vergaren: bij een minimale inbreng van $\$ 1.000 .000$ door de oprichters kunnen aanvullende overheidsleningen verkregen worden tot het viervoudige; voor deze leningen zijn de oprichters niet aansprakelijk. Aldus werd bereikt, dat overheidsgelden geïnvesteerd werden via corporations of partnerships, die gezien de eigen inbreng der oprichters voor de overheid een garantie waren voor zorgvuldig investeringsbeleid; voor de oprichters werd het mogelijk om investeringen van importantie te doen, waarin de verhouding tussen totale investering en eigen risico aantrekkelijk was. Dat het niet bij SBIC's bleef, en ook andere investeringscombinaties werden gevormd, met name via de zogenaamde private partnerships, is begrijpelijk. ${ }^{8}$ Daardoor kreeg het stelselmatig verzamelen van te investeren risicokapitaal een belangrijke stimulans in de vs-economie, en is de uitstraling daarvan in Nederland van groot belang.

Kwamen uit Amerika impulsen voor small business ${ }^{9}$ en omgaan met risicokapitaal, in het kader van dit artikel dienen ook de werkgelegenheidsinitiatieven in Engeland aangestipt te worden.

In het begin van de jaren tachtig zijn door enkele grote bedrijven en regionale overheden in Noord-Engeland initiatieven genomen om werkgelegenheid te creëren op locaal en regionaal niveau. Hieruit kwam voort het fenomeen van de Local Enterprise Agency (afgekort Lenta of LEA). Men stelle zich dit voor als een bureau voor advisering en doorverwijzing voor mensen met plannen voor een eigen bedrijf. Daarnaast zijn bestaande, lege fabrieksgebouwen op simpele wijze verbouwd tot collectieve huisvesting voor jonge ondernemers. ${ }^{10}$ Beide initiatieven hebben de ontwikkeling van lokale werkgelegenheid van kleine ondernemingen sterk gestimuleerd, en geleid tot toepassing van dergelijke formules in heel Engeland.

Hoewel de begeleidingsstructuren voor ondernemers in Engeland en $\mathrm{Ne}$ derland niet eenvoudig vergelijkbaar zijn, kan wel geconstateerd worden dat kennisname en bestudering van bovengenoemde initiatieven inspirerend heeft gewerkt op de ontwikkeling in Nederland van bedrijvencentra, adviesinstanties en vele werkgelegenheidsinitiatieven.

Tenslotte: 'Job Creation'. Dit inmiddels ook in Nederland bekend geworden bureau is in Engeland gestart. De formule is simpel (maar veeleisend): het 
bureau verbindt zich om tegen een bepaalde vergoeding per arbeidsplaats werkgelegenheid te creëren door het aantrekken van nieuwe bedrijvigheid; aangezien ook afspraken worden gemaakt over de minimale duur van zo'n arbeidsplaats, vindt in de aanvangsfase van de onderneming tevens begeleiding plaats. Deze formule vindt in ons land steeds meer verspreiding, en stimuleert het denken over aangepaste dienstverlening aan de jonge onderneming.

Volledigheidshalve zij opgemerkt, dat de gegroeide aandacht voor 'small and growing business' bepaald niet beperkt is tot het bovenstaande. Het elfde International Small Business Congress in Amsterdam (oktober 1984) gaf via de vele congresbijdragen en het gepresenteerde wereldwijde onderzoek van de Stichting Maatschappij en Onderneming (SMO/SKIM) een indrukwekkend beeld van de vele ontwikkelingen op dit terrein in alle werelddelen.

\subsection{Ontwikkelingen in Nederland: lokale werkgelegenheidsinitiatieven en venture capital}

Het resultaat van de in paragraaf 3 besproken klimaatswijziging en de buitenlandse invloeden van paragraaf 4.1 zou ik voor ons land willen samenvatten in de begrippen 'lokale werkgelegenheidsinitiatieven' en 'venture capital'. Deze begrippen hebben raakvlakken, maar zijn overigens duidelijk te onderscheiden.

\subsubsection{Lokale werkgelegenheidsinitiatieven}

Dit is een verzamelnaam voor een veelheid van acties en organisaties, die tot doel hebben de lokale (c.q. regionale) werkgelegenheid te bevorderen, gewoonlijk door de oprichting te stimuleren van nieuwe, kleine ondernemingen. Enkele voorbeelden. ${ }^{11}$

- Ondernemerscentra of bedrijfsverzamelgebouwen. Gewoonlijk door samenwerking van lokale overheid, een bank, een onroerend goedexploitant en soms lokaal gevestigde bedrijven wordt een gebouw verbouwd of nieuw gebouwd voor startende ondernemingen: deze ontvangen naast huisvesting centrale faciliteiten en begeleiding. Bekende voorbeelden: 'Markant' in Almere, 'Rede' in Valkenswaard, Bedrijfstechnologisch Centrum (BTC) Twente, Haags Ondernemerscentrum.

- Lokale stichtingen, samenwerkingsverbanden tussen gemeente en bedrijfsleven, tijdelijke projecten in samenwerking met organisaties van werkgevers/werknemers, die ten doel hebben (aspirant-)starters te adviseren en te begeleiden. Bekendheid verkreeg bijv. de vNO-aktie 'Word je eigen werkgever'.

- Lokale of gedecentraliseerde cursussen, scholingsbijeenkomsten en voorlichting voor de (aanstaande) ondernemer. Voorbeelden: de cursussen van Kamers van Koophandel, idem van CIMK (Centraal Instituut Midden- en Kleinbedrijf)/Regiobaak.

- Fondsen, subsidie- of garantieregelingen, inmiddels ook lokale participatiemaatschappijen; alle bedoeld om het veelvuldig voorkomend tekort aan risicodragend vermogen van de startende onderneming te verkleinen. 
In de afgelopen vijf jaar is door vele overheidsinstanties, adviesinstituten, bedrijven en particulieren een grote hoeveelheid geld en energie gestoken in bovengenoemde acties ten behoeve van 'de startende ondernemer', populair 'de starter'. De vraag is inmiddels ook wel gesteld, of het de moeite waard is geweest, of al deze investeringen hun nut hebben gehad. Harde antwoorden op die vraag lijken niet zo eenvoudig, zo is wel gebleken.

Om wat voor type ondernemingen gaat het hier nu eigenlijk? Op deze vraag is nauwelijks een scherp afgegrensd antwoord te geven. Ambitieus en bescheiden, groeigericht en stabiel, met en zonder sterke winstpotentie, maatschappelijk conformistisch of alternatief, innoverend of meer traditioneel: al deze kenmerken komen voor. Wil men toch deze brede verzameling enigszins afgrenzen, dan lijken mij de volgende typeringen van toepassing:

- gewoonlijk niet 'veelbelovend'; ik kom op dit begrip bij de paragraaf over Venture Capital terug. Thans zij toegelicht, dat hiermee niets negatiefs bedoeld is, maar een afgrenzing ten opzichte van de snelle groeiers, de doorstarters, de marktveroveraars, kortom die jonge ondernemingen, die in enkele jaren een grote groei willen èn zullen doormaken; slechts in zeer beperkte mate treft men dergelijke ondernemers onder de 'starters' aan.

De meeste zullen nooit boven de 'kleine onderneming-grenzen' van BW 2 Titel 8 uitkomen.

- in opzet, marktgerichtheid en organisatorisch denken gewoonlijk kleinschalig; vaak een lokaal/regionale functie, dan wel opererend in een klein segment van een grote markt en tevreden met een redelijk resultaat.

- het 'management' voldoet voor het overgrote deel niet aan criteria als all-round, professioneel, internationaal vaardig, en heeft vaak een wat eenzijdige verkoop- of technische achtergrond. De financieel-administratieve deskundigheid is vaak beperkt, waardoor accountants en andere adviseurs een (soms te) grote rol krijgen toebedeeld.

- voor zover het risicodragend eigen vermogen tekort schiet, wordt dit veelal aangevuld met behulp van de staatsgegarandeerde kredietfaciliteiten. (Vermogensversterkingskrediet, Bedrijfskrediet, Bijzondere hypothecaire geldlening, soms in combinatie met speciale risico- of garantiefondsen van banken en lokale overheden).

Met name vanwege de twee laatste punten is er een veelheid van adviseurs, advies- en begeleidingsinstanties en adviesliteratuur opgekomen, die de 'starter' hulp willen bieden bij het vinden van de juiste wegen en middelen voor realisatie van zijn of haar plannen voor 'een eigen bedrijf'.

\subsubsection{Venture capital ${ }^{12}$}

Om te beginnen volgen hier enkele definities uit deskundige kringen.

'Venture capital is het investeren van risicodragend vermogen in (jonge) veelbelovende ondernemingen met als doel het realiseren van vermogenswinst' (verder aangehaald als de 'NoRo-definitie'). ${ }^{13}$

'Venture Capital is een vorm van investeren waarbij in de meest risicodragende vorm wordt deelgenomen in ondernemingen, bij voorkeur jonge, snel 
groeiende bedrijven, die de potentie hebben om binnen enkele jaren een aanzienlijke plaats binnen hun marktgebied te veroveren' (EDCC-definitie).$^{14}$

De Venture Capital Gids van Peat Marwick (hierna: de VC-Gids van Peat) gebruikt een ruime betekenis, tot uiting komend in 'feitelijke en/of voorwaardelijke deelname in het eigen vermogen van een project of van een onderneming met een meer dan normaal risico-element en een hoge rendementsverwachting', alsmede 'een zekere mate van actieve begeleiding door de Venture Capital Maatschappij'.

Wel aardig is ook: 'The partnership between a man with an idea or a technology and an entrepreneurial financier' (EVCA). ${ }^{15}$

En tenslotte twee vertalingen (afgezien van 'risicokapitaal'): 'participatiekapitaal' (NVP) ${ }^{16}$ en 'durfkapitaal' (Caljé) ${ }^{17}$.

Deze definities en hun onderlinge verschillen werpen nader licht op de historie van venture capital, en bieden enig houvast om een afgrenzing te maken ten opzichte van de lokale werkgelegenheidsinitiatieven.

De EDCC-definitie valt op door enige bijzondere accentuering: 'meest risicodragend', 'binnen enkele jaren', 'aanzienlijke plaats'. EDCC en NORO noemen beide de bij voorkeur jonge ondernemingen als doelgroep, met het adjectief 'veelbelovend' of 'snel groeiend'. Het is een gemeenschappelijk project, blijkens de EVCA-typering "partnership'; de aard van de financiering lijkt mij treffend vertaald door Kees Caljé met 'durfkapitaal'.

Het gaat derhalve om een samenwerking tussen de man $(\mathrm{m} / \mathrm{v})$ met een bijzonder idee, visie op een markt of origineel produkt, die voor de ondernemingsrealisatie daarvan een partner vindt, die in hem gelooft en bereid is een belangrijk financieel risico te lopen - in de gezamenlijke hoop dat de revenuen dienovereenkomstig zullen blijken.

Terecht spreken sommige auteurs van een hèrontdekking, een fenomeen wat 'weer terug' is. Namelijk in die zin, dat een dergelijk samengaan in principe reeds eeuwen oud is. Dit moge zo zijn - belangrijk is in elk geval, dat het risicofinancieren op deze wijze herleefd is. Daardoor zijn ondernemingen mogelijk geworden, die innovatie, nieuwe technologie en fris ondernemen opstuwden tot de thans bekende omvang - en wat ons nog te wachten staat. Zoals reeds eerder vermeld, is het aldus getypeerde 'venture capital' al enkele decennia in de Verenigde Staten actief - mede vanuit Nederlandse bronnen. Doch de laatste jaren geschieden in toenemende mate ook investeringen in Europa, waaronder Nederland.

De beoordeling van de vele voorgelegde ondernemingsplannen en de selectie daaruit van de werkelijk veelbelovende stelt hoge eisen aan de 'venture capitalist'. Het gaat immers primair om een beoordeling van de ondernemer: 'een bedrijf staat of valt met de man of vrouw aan de top'; 'daarnaast moet zijn activiteit uniek zijn of zich in elk geval onderscheiden van al het andere dat op dit terrein gebeurt' ${ }^{18}$. Gewoonlijk hebben de venture funds een klein management-team ${ }^{19}$; de curricula vitae van deze managers vermelden veelal een veelzijdige en langdurige ervaring in het bedrijfsleven. De financiële prognoses in het ondernemingsplan worden niet zonder belang geacht, maar 
spelen geen overheersende rol bij de beoordeling: het blijven immers rekenkundige bewerkingen van vooronderstellingen - en om die vooronderstellingen gaat het nu juist. Hieruit vloeit voort, dat de venture capitalist na investering niet passief gaat toekijken, maar actief bij de ontwikkelingen betrokken wil zijn: de nadere invulling van het partnership.

Gezien de criteria 'snelle groei' vinden de investeringen vaak plaats in de sfeer van high technology en dienovereenkomstig groeien ze met de trends daarin mee; zo viel voor 1984/85 waar te nemen, dat de belangstelling voor applicatiesoftware en microcomputers terugliep, terwijl communicatietechnieken, biotechnologie en medische apparatuur in appreciatie stegen. Overigens geldt in algemene zin, dat elk goed project in principe welkom is; de boven aangeduide voorkeuren ontstaan op grond van produkt/marktinschattingen, die betrekkelijk snel kunnen wijzigen.

De risicodeelname door de venture capitalist is niet voor eeuwig bedoeld; beoogd wordt na een aantal jaren de aandelen af te stoten, waarbij een belangrijke vermogenswinst dient te worden gerealiseerd als beloning voor het geïnvesteerde risicokapitaal. In dit verband is de begin 1982 gestarte en de laatste jaren sterk in activiteit gegroeide Parallelmarkt voor de Nederlandse situatie van groot belang gebleken.

Keren we nog even terug naar de in het begin van deze paragraaf gegeven definities, dan valt op dat de definitie van de vC-Gids (bewust) iets ruimer is (vooral in vergelijking met EDCC): 'meer dan normaal risico-element', 'zekere mate van actieve begeleiding'. Het zijn nuances, maar geen onbelangrijke. Immers, inmiddels zijn ook in Nederland vele fondsen en participatiemaatschappijen actief geworden in het verschaffen van risicokapitaal, doch vanuit verschillende achtergronden. Qua herkomst zou ik hier drie groepen willen onderscheiden.

Ten eerste de venture capital funds, die gesticht zijn vanuit of met particulier risicokapitaal. Deze zou ik de 'zuivere' venture funds willen noemen; zij zijn gesticht om de marktmogelijkheden voor meer dan gemiddelde rendementen te benutten, op basis van ter beschikking staande markt-, management- en financieringsdeskundigheid. Het risico wordt bewust gezocht en aangedurfd. (Dat daarbij principes en technieken worden benut om deze risico's te beheersen, door bijvoorbeeld portefeuillespreiding over verschillende markten en rijpheidsfasen der participaties, en limieten bij de omvang der participaties, laat ik verder buiten beschouwing.)

Ten tweede de participatiemaatschappijen (al of niet 'Particuliere Participatie Maatschappij', dat wil zeggen vallend onder een verliesgarantieregeling vanuit de overheid), die vanuit de (Rijks- of lagere) overheid zijn opgericht. Primair doel van deze oprichting was het behoud van, bij voorkeur de stimulering van werkgelegenheid; in een latere fase ook het bevorderen van innoverend/technologisch hoogwaardig ondernemen. De invalshoek is hier derhalve anders dan bij de eerste categorie: niet de doelstelling 'rendement door risico', maar 'werkgelegenheid/innovatie door risico' (met hopelijk een rendement).

Ten derde de participatiemaatschappijen, die vanuit de bankwereld zijn opgericht. De banken zijn de afgelopen jaren geconfronteerd met de nood- 
zaak van risicodragende financiering bij relaties, waar de gangbare bancaire financiering niet toereikend was. Dit kan ook anders gezegd worden: de gangbare financiering dreigde en bleek steeds risicodragender te worden; een meer zuivere splitsing tussen risicodragend en risicomijdend financieren was daarom gewenst. De doelstelling hierachter zou ik willen omschrijven als: 'meer financiering door risico'. Vanzelfsprekend werd rendement beoogd, maar komend langs een andere weg - en met een andere, namelijk risicomijdende traditie.

Welnu, al deze diverse vormen (beginnend bij 'durfkapitaal', eindigend bij 'participatie'- of zelfs 'risicokapitaal'), zijn in de vC-Gids opgenomen, en logischerwijs moet de definitie daarom ruimer zijn. Overigens valt te verwachten, dat de bovengeschetste historische achtergronden hun betekenis zullen verliezen, naarmate al deze fondsen meer hetzelfde doen - en gaan samenwerken. Dit laatste is een wens van diverse 'venture capitalists'; de eerste blijken van deze samenwerking zijn er reeds, en mogelijk zal dit betrekkelijk snel in omvang toenemen. Doch momenteel acht ik het nog van belang, dat deze verschillende achtergronden door de venture-ondernemer en zijn adviseurs onderkend worden, teneinde in de gegeven situatie de meest passende bronnen aan te boren; minder tijdverlies, sneller begrip en overeenstemming zijn vitaal.

Een enkel woord nog over de management buy-outs, in het Engelstalige verkeer veelal ook omschreven als 'leveraged buy-outs'. Deze zijn de laatste tijd sterk in opkomst, en vermoedelijk blijft dit nog wel even zo. 'Van een buy-out is sprake indien een eigenaar wordt uitgekocht. Verzelfstandiging betekent dat iets wordt losgemaakt uit een groter geheel' (R. Snoeker). ${ }^{20}$ Buy-out en verzelfstandiging zijn derhalve niet synoniem, maar gaan wel vaak samen. Kwik onderscheidt drie soorten: de offensieve (waarbij succesvolle nevenactiviteiten en dergelijke worden afgesplitst), de defensieve (vaak uit overwegingen van sanering, rendementsverbetering) en tenslotte de categorie, waarbij een concern zich gaat beperken tot strategisch geoordeelde hoofdactiviteiten en daarom nevenactiviteiten wil afscheiden, die niet passen in de hoofdactiviteiten. Gewoonlijk worden deze buy-outs in sterke mate met vreemd vermogen gefinancierd (vandaar: 'leveraged'), omdat de directieleden/mede-eigenaars onvoldoende eigen middelen bezitten. Het 'venture capital' interesseert zich bijzonder voor deze buy-outs, omdat hier een bedrijfshistorie beschikbaar is en de risico's derhalve meer overzienbaar lijken. Bovendien gaat het regelmatig om grote bedragen, waardoor van aantrekkelijke projecten sprake kan zijn.

\section{Afgrenzing en evaluatie}

5.1 Thans kan een poging worden gedaan de begrippen 'lokale werkgelegenheidsinitiatieven' en 'venture capital' af te bakenen ten opzichte van elkaar.

Om te beginnen zijn er overeenkomsten: beide hebben betrekking op veelal jonge en risicovolle ondernemingen. Maar de verschillen zijn aanzienlijk groter. 'Lokale werkgelegenheidsinitiatieven' zijn veelal geboren uit de 
behoefte aan nieuwe arbeidsplaatsen; de mate van succes wordt vaak gemeten aan de omvang der duurzaam gerealiseerde arbeidsplaatsen. 'Venture capital'-ondernemingen beogen echter een hoog rendement door een bijzondere produkt/marktcombinatie; het succes van venture capital wordt dientengevolge veelal uitgedrukt in termen van rendement en vermogenswinst. Lokale werkgelegenheidsinitiatieven leiden daardoor veelal niet tot ondernemingen, die 'veelbelovend' zijn, sterk zullen groeien, een aanzienlijk marktaandeel zullen verwerven, en uiteindelijk grote vermogenswinsten mogelijk maken. Het management heeft gewoonlijk minder ambities en minder professionele deskundigheid dan dat in de sfeer van venture capital. Zulks impliceert voor de ondernemingen uit de 'lokale' sfeer een kleinschalig karakter, in horizon vaak beperkt tot nationaal of zelfs regionaal niveau. Zij zullen kleine ondernemingen blijven, terwijl de venture capitalondernemingen de potentie en aspiratie hebben een middelgrote of grote onderneming te worden. De behoefte aan externe ondersteuning en advies op deelgebieden is bij de 'lokale' groter dan bij de 'venture capital'-ondernemingen. En als ik het vanuit mijn professie definieer: de 'lokale' zullen cliënten zijn voor de accountant-administratieconsulent, de 'venture capital' daarentegen voor de registeraccountant.

Vanzelfsprekend zijn er overlappingen: uit 'ondernemerscentra' komen spectaculaire groeiers voort, en met 'venture capital' gefinancierde ondernemingen blijven soms steken in kleinschaligheid. Maar dat is een normale definitieverstoring.

5.2 De betekenis van 'lokale werkgelegenheidsinitiatieven' en 'venture capital' voor de Nederlandse economie valt nog niet eenduidig te waarderen. Onlangs werd een (voor)onderzoek afgesloten naar de mogelijke meerwaarde van lokale werkgelegenheidsinitiatieven ten opzichte van de traditionele adviescircuits uit oogpunt van nutsrealisatie voor de betrokken ondernemingen en/of andere participanten, zoals overheden en particuliere exploitanten ${ }^{21}$. Uit dit vooronderzoek viel te concluderen, dat gedeeltelijk 'slechts' kwalitatieve (in tegenstelling tot kwantitatieve) uitspraken verwacht mogen worden uit een breed op te zetten onderzoek. Dat de vele inspanningen rond startende ondernemingen feitelijk nut hebben gehad, en meer baten dan lasten hebben opgeleverd, is wel een in brede kring beluisterde opinie, maar daarmee nog geen bewezen feit. Immers, wat zijn de netto baten voor onze economie van deze initiatieven ná aftrek van de vele gemaakte kosten en gepleegde investeringen, rekening houdend met de verhoogde omvalkans in de eerste bestaansjaren van de onderneming?

Desalniettemin: de kwalitatief uitgesproken waardering valt niet te verwaarlozen (zie ook het onderzoeksverslag, vermeld onder noot 10). De lokale initiatieven hebben veel werkgelegenheidsenthousiasme en -creativiteit losgemaakt. Ook het accountantsberoep heeft dat ondervonden. Hernieuwde aandacht ontstond voor de beoordeling van prognoses, het opstellen van liquiditeitsbegrotingen met toenemende verfijning, het meedenken over de opbouw van jonge organisaties en de analyse van kansen en risico's. Op grond daarvan lijkt de indruk gerechtvaardigd, dat de lokale werkgelegenheidsinitiatieven een verfrissende stimulans hebben betekend voor vele 
betrokkenen, en aldus een wezenlijke bijdrage hebben geleverd aan werkgelegenheidsbevordering en de realisatie van levensvatbare nieuwe ondernemingen. De leereffecten leiden ook tot enige professionalisering; er is meer inzicht ontstaan in kritische overlevingsfactoren en de slagingskans van werkgelegenheidsprojecten al naar gelang de organisatorische opzet en begeleiding. Verwacht kan worden, dat nieuwe projecten een meer zakelijke toetsing zullen ondergaan dan in de aanvangsfase; die toetsing maakt echter een ruimere beschikbaarstelling van risicokapitaal mogelijk, waardoor de stelling 'een goed bedrijfsplan valt (bijna) altijd te financieren' aan kracht wint. Diverse grote banken hebben inmiddels daartoe specifieke risicofondsen gevormd, gericht op de kleine nieuwe onderneming.

Op dit punt raken de 'lokale werkgelegenheidsinitiatieven' wederom de wereld van het 'venture capital'. Ook daarmee is inmiddels de nodige ervaring opgedaan. Het aantal venture capital fondsen is snel gegroeid, evenals het daardoor ter beschikking komende kapitaal. Waar echter de beschikbaarheid van risicokapitaal thans ruim voldoende mag worden genoemd, is tegelijkertijd de aanwending problematischer geworden. Na 1983 zijn de resultaten van veel venture-ondernemingen nogal tegengevallen. De daardoor toegenomen behoedzaamheid bij kapitaalverschaffers, gecombineerd met het gegroeide aantal aanbieders, maakt de spoeling wat dun; in het venture-veld valt dan ook een toenemende en gerichte acquisitie naar goede projecten waar te nemen. Illustratief was een zinsnede in een Survey van de Financial Times: 'Venture capitalists in the UK and all over Europe are, however, complaining of a serious shortage of investment opportunities of the right-quality, especially among start-up businesses'. ${ }^{22}$ Dientengevolge is er een begrijpelijke verschuiving naar 'more mature companies and particularly to management buy-outs' - zoals ook aan het slot van paragraaf 4.2.2 werd geconstateerd. Mijns inziens terecht wordt er elders in dezelfde Survey geconstateerd, dat dit een niet onbelangrijke aandachtsverschuiving betekent van de ontwikkeling van 'small businesses' naar 'corporate finance'. Niet verrassend is, dat de 'gewone' banken daarbij weer meer in beeld komen. Zeker in die gevallen, waarbij buy-outs een redelijk eigen vermogen meekrijgen (in welke vorm dan ook) van de verkopende onderneming, kunnen de nieuwe eigenaars het benodigde vreemde vermogen met minder moeite (en soms ook goedkoper) bij een bankier verkrijgen dan in het geval van de jonge, snel expanderende onderneming. Het zou niet verrassend zijn, als dientengevolge enige venture fondsen weer geruisloos verdwijnen.

De vraag kan dan rijzen, in hoeverre de opkomst en financiering van nieuwe ondernemingen een spiraalvormige ontwikkeling heeft doorgemaakt. Toen een aantal jaren geleden onvoldoende risicodragend kapitaal beschikbaar was, en de banken daar om begrijpelijke redenen onvoldoende in konden bijdragen, is door de opkomst van lokale werkgelegenheidsinitiatieven en venture capital fondsen in deze lacune voorzien. Zelfstandig ondernemen en in risico investeren onderging toen een opwaartse waardering. In dit klimaat werd de concentratie van ondernemingen op kernactiviteiten en 
het verzelfstandigen van daarbij niet goed (meer) passende nevenactiviteiten steeds meer realiseerbaar. Tenslotte blijkt dan de financiering daarvan voor de banken weer meer toegankelijk.

Zeker, dit beeld is wat gestileerd. Want zelfs voor zover deze beweging juist geschetst is, moet daar in één adem aan worden toegevoegd dat de bankier van vandaag - evenals de accountant - heeft moeten meegroeien. Het opstellen van goed onderbouwde ondernemingsplannen, de toegenomen aandacht voor cash flow begrotingen ten opzichte van resultaten prognoses, en het periodiek opstellen van goede managementrapportage en analyseren van kansen en risico's geschiedt thans aanzienlijk vanzelfsprekender èn deskundiger dan voor deze ontwikkeling. ${ }^{23}$ Verdere verdieping hierin is voor alle betrokkenen geboden.

En overigens ben ik van mening - om in klassieke stijl te eindigen - dat het fiscaal faciliëren (dat wil zeggen minder difficiliëren) van risicoinvesteringswinsten en -vermogens te prefereren is boven het subsidiëren van verliezen.

\footnotetext{
Noten

1 Uitgave Tjeenk Willink, Zwolle, tweede (gewijzigde) druk 1985. Hierna aangehaald als 'Degenkamp c.s.'

2 Oktober 1985. Gewijzigd en uitgebreid ten opzichte van de editie 1984. Hierna aangehaald als de 'VC-Gids' van 'Peat', omdat de afkorting 'PMN' verwarring kan oproepen vanwege de reeds bestaande begrippen PPM en PMM.

3 Een feitelijke enquête in Almere leerde mij (najaar 1985), dat de ABN alleen mondelinge informatie verstrekte; Amro, NMB en Rabo hadden echter relevant en helder voorlichtingsmateriaal. Een selectie daaruit.

Amro: diverse brochures over $B V^{\prime}$ 's, kredietuormen, pensioenen en bedrijfsfinanciering.

NMB: het bekende werkboek 'Een eigen bedrijf beginnen'; een veelzijdige checklist met toelichting.

Rabo: 'Plannen voor een eigen onderneming'; globaal, maar breed; verlucht met interviews. 4 In het verleden zijn reeds meer boeken voor startende ondernemers verschenen, onder andere diverse van de hand van Ir. H. H. Veurtjes (zeer praktisch gericht), en 'Welkom in Ondernemersland', 1983. Voor starters acht ik de praktijkgeschreven boeken nog het meest bruikbaar; vergelijk het recentelijk verschenen 'Originele ideeën voor het starten van een succesvol bedrijf' door Herman Dirk, 1985, een bundel interviews met gestarte ondernemers. 5 Aldus drs. A. H. J. Risseeuw op de NORO-congresmiddag 'De ondernemer aan het woord', 1 oktober 1985. Over deze ontwikkelingen vindt men meer in: Kees Caljé, Ondernemen op eigen kracht, Het einde van het conglomeraat, Utrecht 1985.

$6 \mathrm{Er}$ is veel discussie geweest over de duurzaamheid van de nieuwe banen vanuit de small business, alsmede de relatieve importantie ten opzichte van de totale werkgelegenheid. Onmiskenbaar is er een hoge 'failure rate' in de eerste levensjaren van de nieuwe onderneming, en logischerwijs is de blijvende werkgelegenheid in de categorie tot twintig werknemers lager dan gemiddeld. Desalniettemin constateren diverse statistieken een netto positief saldo werkgelegenheidsaanuas vanuit de small business.

Belangrijke onaerzoeksconclusies in deze richting van de Amerikaan David Birch werden genuanceerd bevestigd in de International Small Business Survey, een onderzoek onder 4000 ondernemers in elf landen door SMO en SKIM, 1984 (onder andere Tabellen 7 en 8). Zie voorts onder meer: The state of small business. A report of the President, Washington 1984, p. 235/236; 'Small Business, Source of Recovery', congresbijdrage James C. Sanders (administrator Small Business Administration USA) op het elfde Internationale Small Business Congress, Oktober 1984, Amsterdam; Michael Scott, Mythology and misplaced pessimism, in: Stimulating Small Firms, uitgave Gower, 1981.

7 Illustratief hiervoor is de populariteit van boeken, die het geheim van succesvol ondernemen trachten te ontrafelen (biju. het bekende 'In search of excellence' van T.J. Peters en $R$. $H$. Waterman jr., 1982; Ned. vertaling 'Excellente ondernemingen', Utrecht 1983) of de achterliggende culturele waarden (biju. L. M. Miller, Naar een nieuwe ondernemingscultuur, Utrecht 1985). Wanneer men de (in beide gevallen: acht) kenmerken beziet, die de auteurs beschrijven, herkent men veel van de 'spirit'van de kleinere onderneming. Peters/Waterman noemen. actiegerichte oriëntatie, klantgerichte instelling, autonomie en ondernemingsgeest, produk-
} 
tiviteit door inzet van mensen, persoonlijke inzet en waardenbewustzijn, schoenmaker blijf bij je leest, eenvoudige organisatie met kleine staf; vrijheid in gebondenheid. Als 'belangrijkste les' uit hun onderzoek geven de auteurs: 'Onderzoek je waardensysteem. Ga eens na wat je onderneming betekent' (p. 322). Dat laatste gebeurt in het boek van Miller, die acht fundamentele waarden beschrijft: de principes doelgerichtheid, eenstemmigheid, uitmuntendheid, eensgezindheid, prestatiegerichtheid, intellectuele vaardigheid, geborgenheid en integriteit. Geheel in lijn hiermee is de (her-?)ontdekking van 'business ethics' in de USA (prof. $d r$. $H$. J. L. van Luijk: Produktie niet meer het hoogste doel, in: Elseviers Magazine, 13 juli 1985 en: In het belang van de onderneming, oratie Nijenrode november 1985) en hier te lande (Aad Huys: Het culturele geweten van de onderneming, in: Management Totaal, augustus/september 1985).

8 Beschrijuingen van deze SBIC's onder meer in het emissieprospectus april 1984 van de European Development Capital Corporation (EDCC) NV, de VC-Gids 1984 van Peat, en in: Drs. H. H. van der Koogh, Ventures en Venture-kapitaal, Economisch Statistische Berichten, 26 oktober 1983.

9 De definities van 'Small Business' lopen uiteen. Primair wordt gewoonlijk benadrukt de onafhankelijkheid en het bescheiden marktaandeel (biju in 'Help for growing Business', uitgave Department of Trade and Industry, London 1984, en de 'Small Business Act' van 1953 in de USA). Soms worden daar omzet-en balanscriteria aan toegevoegd. Het maximum aantal werknemers wordt veelal op 100 gesteld, maar 200 (UK) of 300 (Japan) of 500 (USA) kan ook voorkomen.

Zie onder meer H. J. Bocker 'Small Business Today - Canada, South Africa and The United States - A Comparison', in: Journal of Small Business Canada, Summer 1983; Small Business in Japan, uitgave van het MITI, 1984, Appended Table 2. Voorts: W. Bos, Samen op weg, oratie Eindhoven 1985, p.4.

10 Inzake de Lenta's kan onder meer als literatuurverwijzing genoemd worden:

- Local Enterprise Agencies, A new and growing feature of the Economy, uitgave Deloitte Haskins \& Sells UK, 1984.

The impact of local enterprise agencies in Great Britain, februari 1985; onderzoeksverslag van het Centre for Employment Initiatives. (Volledigheidshalve zij opgemerkt, dat dit onderzoek niet al te diepgaand lijkt, maar desalniettemin een duidelijk beeld geeft van het Lenta-enthousiasme.)

11 Literatuur onder meer:

- Atlas van lokale initiatieven in Nederland, 1984 (tekstdeel 'Stimulering van bedrijuigheid en werkgelegenheid').

- Lokale initiatieven, theorie en praktijk, Kluwer 1984 (Congresbundel).

- Lokale werkgelegenheidsinitiatieven in Nederland (Verslag EG Consultatie 1984), eindred. Drs. Leo Verhoef e.a.

12 Bij dit onderdeel zijn de navalgende jaarverslagen 1984 geraadpleegd: NV Bever Beleggingen; Oranje Nassau Groep; European Development Capital Corporation (EDCC) NV; Maatschappij voor Industriële Projecten NV; MK International Ventures NV; Nederlandse Participatie Maatschappij NV.

Overige geraadpleegde literatuur, voor zover niet reeds vermeld:

Een kapitalmarkt voor jonge ondernemingen, Dr. E. P. M. Tervooren (Bank ITEC), 1982; Congresbijdragen 54e Dies Kring van Amsterdamse Economen (mei 1983) van Dr. E. P. M. Tervooren en Drs. A. Wateler; Nesbic - Groep van participatiemaatschappijen, 1985; Guide to European Venture Capital Sources, uitg. Venture Economics, 1985; David Gladstone, Venture Capital Handbook, 1983; David Silver, Who's who in Venture Capital, 1984; idem, Venture Capital, 1985; Risicodragend vermogen, een verkenning, NMB Bank 1984; Raising Venture Capital, An Entrepreneur's Guidebook, Deloitte Haskins \& Sells 1984. Roland van Dierdonck, Management van de snelle groei, in: A\& B, Kwartalschrift, 1985-2.

Congresbundels: 'Ondernemers op zoek naar risicokapitaal', NCD 1985; Venture Capital + De Onderneming, Intermediair 1985; Management Buy-Out, Samsom Seminars 1985.

13 J.A. Fentener van Vlissingen in een paper, uitgereikt op de congresmiddag 'De ondernemer aan het woord', 1 oktober 1985, ter gelegenheid van het tienjarig bestaan van 'The Noro Group of Companies'.

14 Emissieprospectus 1984 EDCC, p. 7

15 Raising Venture Capital, An Entrepreneur's Guide Book, uitgegeven door de European Venture Capital Association (EVCA) tezamen met Deloitte Haskins \& Sells, 1984, p. 7.

16 NVP-Bericht (Nederlandse Vereniging van Participatiemaatschappijen), augustus 1985. 17 Kees Caljé in de NRC van 3 oktober 1985.

18 Aldus drs. A. Kloezen van Euroventures in de NRC van 8 oktober 1985.

19 Silver's 'Who's who' (noot 10) vermeldt \pm 260 'venture funds' tegenover \pm 700 'venture capitalists', een verhouding van circa 1 op 3 dus. 
20 Zie naast eerdergenoemde literatuur ook P. M. Koster, RA, Een leveraged buy-out, in 'De accountant', oktober 1985. Voorts:

R. Kwik, Management buy-outs nog in opkomst, en R. Snoeker, Verzelfstandiging (buy-out), in: Tijdschrift Financieel Management, 1985/4.

21 Bakkenist, Spits en Co, Vooronderzoek naar de meerwaarde van lokale initiatieven, Rapport uitgebracht aan Ministerie van Sociale Zaken e.a., december 1985.

22 Venture Capital, Financial Times Survey, December 3, 1985.

23 Vergelijk nog L. Deuzeman, Het aantrekken van risicodragend vermogen, Harvard Holland Review, Nr. 5, 1985. 